Article

\title{
Investor Overconfidence and Trading Activity in the Asia Pacific REIT Markets
}

\author{
Helen X. H. Bao *(i) and Steven Haotong Li \\ Department of Land Economy, University of Cambridge, Cambridge CB3 9EP, UK; haotongsteven@cantab.net \\ * Correspondence: hxb20@cam.ac.uk
}

Received: 28 August 2020; Accepted: 26 September 2020; Published: 29 September 2020

\begin{abstract}
Overconfidence is one of the most robust behavioral anomalies in financial markets. By attributing investment gains to their ability, investors become overconfident and trade aggressively in subsequent periods. Evidence from stock markets shows that overconfidence leads to excessive trading and, subsequently, inferior investment performance. However, studies on overconfidence effect are lacking in the real estate sector, which is particularly true for Asia Pacific real estate investment trust (REIT) markets. Thus, this study examines the overconfidence effect in six Asia Pacific REIT markets, namely, Australia, Hong Kong, Japan, Singapore, South Korea, and Taiwan. The study finds that the overconfidence effect is more conspicuous during market boom periods or in inefficient market conditions. In addition, simulation analysis demonstrates that overconfidence could lead to rather large volumes of excessive trading activities in certain markets. Findings are robust across the alternative measures of control variables. Moreover, the policy implications of the research are also discussed.
\end{abstract}

Keywords: judgmental bias; behavioral finance; investment decision; real estate

JEL Classification: G12; G15; G41

\section{Introduction}

Economists have long found it difficult to justify investors' enthusiasm for active trading in financial markets. Rational investors trade when liquidity demand emerges and when they need risk hedging or portfolio rebalancing. However, evidence affirms that investors regularly trade too frequently, especially in bull markets (Griffin et al. 2007; Odean 1999; Shiller 1981, 1983). Such active trading behavior is significantly related to poor subsequent investment performance (Barber et al. 2009; Barber and Odean 2000, 2001; Kuo and Lin 2013). Among many factors, overconfidence is the simple and powerful explanation for the excessive trading activity (Barber and Odean 2001; Odean 1998).

Overconfidence is one of the most persistent and significant phenomena in the psychology of judgment (De Bondt and Thaler 1985). More than half of investors consider their investment skills better than the average level (Glaser and Weber 2007; Statman et al. 2006). In addition, people exhibit considerable precision regarding their own information but have less precision toward public information (Daniel et al. 1998; Odean 1998). Over the past decades, this topic has attracted growing interest from academia and the industry, particularly in the financial sector. Evidence validates that overconfidence has significant implications on investment decisions, such as saving behaviors and motives (Sakalaki et al. 2005), retirement planning (Parker et al. 2012), stock trading frequency (Glaser and Weber 2007; Statman et al. 2006), and stock market participation (Xia et al. 2014). Most importantly, overconfidence negatively affects investment performance (Daniel et al. 1998; Hanauer 2014; Janus et al. 2013). 
Although research on overconfidence improves our understanding of investor behaviors, current studies mainly focus on stock markets. The real estate market has not received sufficient attention in this stream of research. A healthy real estate market is vital for the macroeconomy of the state in the long run (Bates et al. 2015). However, the uniqueness of the asset class also subjects investors to behavioral biases. For instance, evidence verifies that real estate prices are affected by the confidence level of investors (Zheng et al. 2016). Homeowners tend to systematically overestimate their home value during market downturns (Chan et al. 2016). One may suspect that overconfidence also affects investor behaviors in the real estate market. Yet this interesting hypothesis remains untested. This paper aims to bridge this gap.

The study focuses on Asia Pacific real estate investment trust (REIT) markets. The recent decade witnessed a rapid growth of the Asia Pacific REIT market in terms of the number of REITs and market capitalization. In 2016, the Asia Pacific region had 268 REITs, 63 of which are included in the EPRA REIT index. The two figures are larger than those in Europe, which have 139 REITs in total, and 59 of them are included in the EPRA REIT index. In 2018, listed real estate companies and REITs in the Asia Pacific region constitute $34.23 \%$ of the FTSE/EPRA/NAREIT Global Index, which is higher than the percentage of those in Europe (i.e., $16.61 \%)^{1}$. By 2020, the total number of listed real estate companies and REITs included in the EPRA REIT index is 180 and 109 for the Asia Pacific region and Europe, respectively. The annualized return between 2016 and 2020 is 5.9\% for the EPRA NAREIT Asia Pacific Index and only 1.7\% per year for the EPRA NAREIT Europe Index. These numbers signify a remarkable growth and development potential in the future for the Asia Pacific region. We suspect that overconfidence plays a significant role in these fast-growing markets, and consequently set up this research to verify this hypothesis.

Moreover, most Asia Pacific REIT markets are not as efficient as those in developed REIT markets, such as the US. Despite the rapid development and the increasing attention to investment in the recent decade, Asian REIT markets are relatively immature. For instance, South Korea and Taiwan markets have short sale restrictions, and several markets have a low transparency level. Discrepancies also exist regarding political risk, legal system, corruption level, and disclosure degree in the Asia Pacific real estate markets (Cashman et al. 2014, 2016). Evidence from stock markets corroborates that inefficient markets (e.g., markets with a low transparency level or short sale constraints) are prone to overconfident trading (Chuang et al. 2014; Griffin et al. 2007). Furthermore, existing studies that investors in the US REIT market exhibit an overconfident trading behavior, which is similar to stock traders (Lin et al. 2010). If this effect remains true for Asia Pacific REITs, a strong overconfidence effect is expected. Therefore, testing the overconfidence hypothesis in the fast-growing Asia Pacific REIT markets is important.

The study evaluates one of the most robust findings about the effect of overconfidence, that is, the increase of trading volume (Odean 1998). Evidence from stock markets confirms that overconfidence and trading activity are positively associated (Chuang and Lee 2006; Statman et al. 2006). Trading activity is connected to previous market returns through overconfidence. Specifically, overconfident investors mistakenly interpret previous market gains as their superior ability to select stocks and, consequently, trade more frequently in the future (Gervais and Odean 2001). Do real estate investors also exhibit overconfident trading behavior? Specifically, in the aggregate level, do previous gain results in a significant increase in trading volume? This is the first research question to be answered in this paper.

Subsequently, the relation between market features and overconfident trading is considered. If overconfidence affects investor behaviors in the Asia Pacific REIT markets, does the effect vary according to market settings? Every REIT market in the Asia Pacific region is unique in terms of regulation, structure, openness, and development direction, providing the study a significant

1 Source: EPRA/NAREIT Global and Global ex US indices Factsheet. (www.ftse.com/products/indices/epra-nareit.html). 
opportunity to compare the overconfidence effects in different market settings. This question is particularly relevant to policymakers and regulators in the Asia Pacific region. The answers to this question could assist the design of policies and regulations to vigorously protect investors from irrational investment behaviors (e.g., overconfident trading).

Finally, if overconfidence and trading volume are related, then does the relationship vary with time? Specifically, investors in up- and down-markets may behave differently under the influence of overconfidence. In stock markets, the overconfidence effect on trading is profoundly conspicuous in bull markets (Chuang and Lee 2006). As REITs behave similarly to stocks (Glascock et al. 2000; Nneji et al. 2013; Yang et al. 2012), the asymmetric overconfidence effects may also exist in REIT markets. This is the third research question to be answered in this study.

The empirical implementation involves data from six Asia Pacific REIT markets (i.e., Japan, Australia, Hong Kong, Singapore, South Korea, and Taiwan) from 1994 to 2015. The vector autoregression (VAR) model is used to explore the return-turnover dynamics and impulse response functions to trace the influence of previous return shocks on market turnover. A significant and positive overconfidence effect is identified regarding the market turnover in South Korea, Taiwan, Japan, and Singapore REIT markets. The effect is particularly strong in less efficient markets with short sale restrictions and low market transparency (i.e., in South Korea and Taiwan). With the re-estimation of the VAR model with up- and down-market sub-samples separately, we found a stronger overconfidence effect in the up-market for Japan, Singapore, and South Korea REIT markets.

The rest of this paper is structured as follows: Section 2 presents the theoretical framework and testable hypotheses. Section 3 introduces data and empirical methods. Section 4 provides the empirical results and discussions, and Section 5 indicates the robustness checks. Finally, Section 6 concludes the paper.

\section{Theoretical Framework and Testable Hypotheses}

Odean (1998) conducted the first systematic analysis of overconfidence and its influence on the stock market. By adding an overprecision condition to the rational microstructure framework of Grossman and Stiglitz (1980) and Kyle (1985), Odean (1998) derived a new market equilibrium under overconfidence. Building upon the work of Odean (1998), Gervais and Odean (2001) developed a self-learning model that describes how investors become overconfident by learning from their investment performance. Specifically, investors attribute their past success to their own ability to select stocks, which boosts their confidence and subsequently leads to excessive trading volume in the future. These studies offer a behavioral explanation to excessive trading volume, a long-standing anomaly in the stock market.

Following these theoretical studies, a body of literature has empirically examined the overconfidence effect on generating trading volume. For instance, Statman et al. (2006) identified a significant lead-lag relationship between turnover and return in the US stock market. On aggregate, market-wide trading activity increases following previous market gains as a consequence of overconfident trading behavior. Therefore, the first testable hypothesis is developed as follows:

Hypothesis 1. On the market level, the current trading activity of REITs is positively related to past market return.

Specifically, the relationship between trading activity and market return can be represented by Equation (1) below, without losing any generality.

$$
\operatorname{TURN}_{t}=f\left(R E T_{t-1}\right)
$$

where TURN $N_{t}$ is the market turnover of REITs in period $t$ and $R E T_{t-1}$ is the market return of REITs in period $t-1$. If Hypothesis 1 is true, then $\frac{d f\left(R E T_{t-1}\right)}{d R E T_{t-1}}>0$. 
After the lead-lag relationship between turnover and return has been established in the literature, researchers explored the dynamics of this relationship in different market conditions. Using data from the stock markets of 46 countries, Griffin et al. (2007) proved that the lead-lag relationship between return and turnover is particularly strong in countries with opaque, volatile, and inefficient financial markets. Similar findings are also found in Asian stock markets, where the relationship is more pronounced in markets with short sale restrictions (Chuang et al. 2014). Short selling restrictions in the real estate sector can create overvaluation and contribute to long bubble periods (Chen et al. 2012; Ikromov and Yavas 2012). A transparent real estate market is also linked to rational behaviors. For instance, in a study on real estate mutual funds, the herding behavior is low in transparent real estate stocks (Ro and Gallimore 2014).

Asia Pacific REIT markets differ in their regulatory requirements, as certain markets have short sale constraints, and some of them have a relatively low transparency level. Investors in these emerging economies are more prone to behavioral bias because these economies have more constraints, strong market governance, and high opaqueness, especially when as regards overconfidence (Chuang et al. 2014; Griffin et al. 2007). Therefore, Hypothesis 2 is derived as follows:

Hypothesis 2. Inefficient REIT markets (i.e., markets with a low transparency level and short sale constraints) are more prone to overconfidence.

If Hypothesis 2 is true, we expect that:

$$
\frac{d f\left(R E T_{t-1} \mid \text { inefficient market }\right)}{d R E T_{t-1}}>\frac{d f\left(R E T_{t-1} \mid \text { efficient market }\right)}{d R E T_{t-1}}
$$

Another moderator of the overconfidence effect is market condition. As people tend to be more confident when gaining profit, it is reasonable to assume that overconfidence effect is prominent in bull markets. Both theoretical and empirical overconfidence literature supports such a claim. For instance, Chuang and Lee (2006) found that the increase of turnover to return is asymmetric in bull and bear markets, with a more prevalent response in bull markets. Thus, the study aims to determine how the return-turnover relationship changes with the market conditions of REITs. Thus, the third testable hypothesis is as follows:

Hypothesis 3. The overconfidence effect is more significant in up-market conditions than in down-market ones.

If Hypothesis 3 is true, then we expect that:

$$
\frac{d f\left(R E T_{t-1} \mid \text { up market }\right)}{d R E T_{t-1}}>\frac{d f\left(R E T_{t-1} \mid \text { down market }\right)}{d R E T_{t-1}}
$$

\section{Data and Models}

Data were collected from six Asia Pacific REIT markets, namely, Singapore, Japan, South Korea, Hong Kong, Taiwan, and Australia. The sampling period of each market is from the earliest available time in Datastream (see the second column in Table 1) to March 2015. Figure 1 shows the total number of REITs and the market capitalization of the six Asia Pacific markets combined from 2001 to 2015. Given that the REIT market of Australia has a longer history than that of the other five Asian REIT markets, a separate market capitalization series is also produced (i.e., the Asia market cap series) for Asian REIT markets, excluding that of Australia.

The Asia Pacific REIT markets developed rapidly between 2001 and 2007. However, upon the onset of the global financial crisis in 2007, the market capitalization and the number of REITs plummeted sharply. The markets have slowly recovered since 2009 and quickly gained momentum again. At the end of 2014, the Asia Pacific REIT markets exceeded the peak in 2007, reaching a total market 
capitalization of 256 billion USD. The number of REITs also increased from 102 in December 2009 to 164 in December 2014. In comparison, the growth in the Asian REIT markets (i.e., excluding Australia) is even more impressive. The recovery from the global financial crisis in Asian REIT markets is stronger than that in Australia. The market capitalization stood at 180 billion USD in early 2015, which is more than three times of the pre-crisis peak in 2007. In sum, the Asia Pacific REIT markets have been growing rapidly in recent years. The strong growth trend in Figure 1 suggests an increasingly important role of the Asia Pacific REIT markets in the global economy.

The original data set of this study contains REIT price, trading volume, and the number of outstanding shares in daily and monthly frequencies. The following transformations are carried out to generate the variables used in the final analysis.

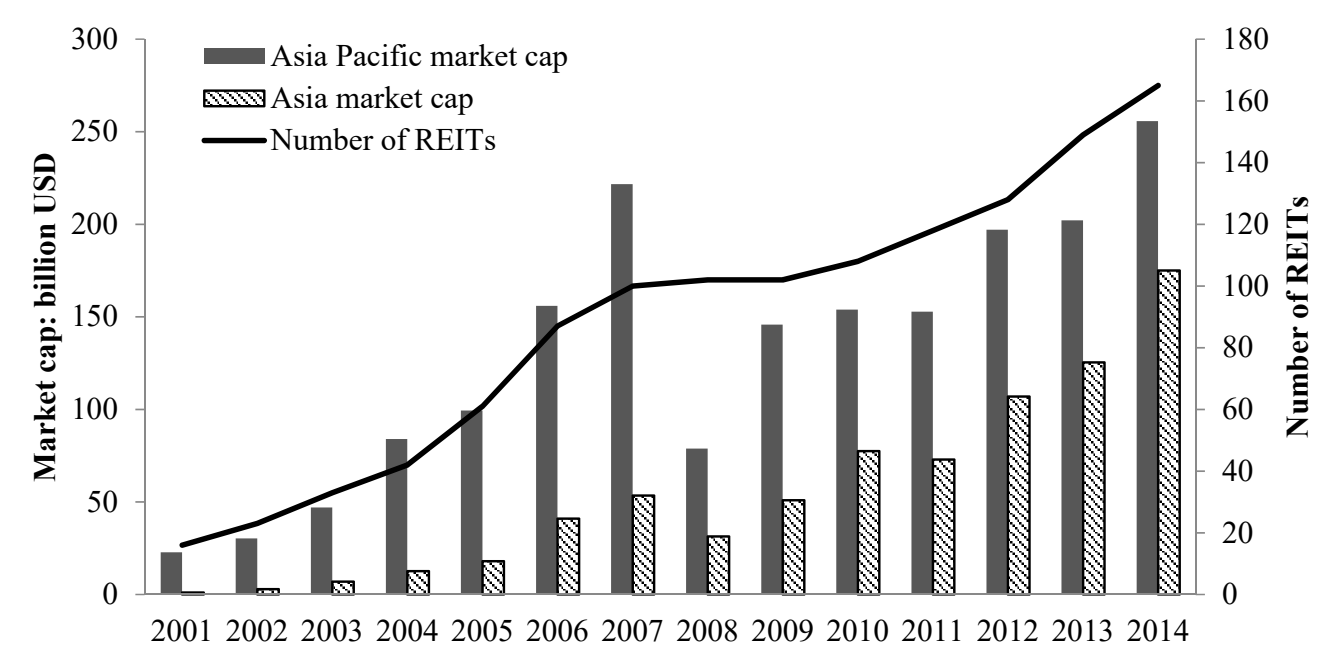

Figure 1. Real estate investment trust (REIT) market growth in the Asia Pacific region.

\subsection{REIT Returns}

Monthly REIT returns are calculated by taking the log difference of REIT prices in two consecutive months (Equation (2)).

$$
r_{i, t}=\log \left(\frac{P_{i, t}}{P_{i, t-1}}\right)
$$

where $r_{i, t}$ is the return of REIT $i$ in month $t$ and $P_{i, t}$ and $P_{i, t-1}$ are the price of REIT $i$ in month $t$ and month $t-1$, respectively.

We define market return as the value-weighted monthly return of all individual REITs in each corresponding market. The weight of each REIT in a specific month is the individual REIT capitalization divided by the overall market capitalization of all REITs in the same market.

$$
\operatorname{RET}_{k, t}=\frac{\sum_{i=1}^{n} P_{i, t} \times S_{i, t} \times r_{i, t}}{\sum_{i=1}^{n} P_{i, t} \times S_{i, t}}
$$

where $R E T_{k, t}$ is the market return for market $k$ in month $t$ and $S_{i, t}$ is the number of outstanding shares of REIT $i$ in month $t$ within market $k$.

\subsection{Trading Turnover}

Although monthly trading volume is a natural indicator of trading activity, it usually varies according to the number of outstanding shares. To remove this confounding factor, the study follows the method by Lo and Wang (2000), in which the trading volume is divided by the number of outstanding shares (Equation (4)).

$$
T_{i, t}=\frac{V_{i, t}}{S_{i, t}}
$$


where $V_{i, t}$ is the trading volume of individual REIT $i$ in month $t$.

For the calculation of market turnover, the monthly value-weighted turnover rate of all REITs in a specific market is obtained. As the resultant turnover series is highly skewed, a natural log transformation is performed (Equation (5)).

$$
\operatorname{TURN}_{k, t}=\log \left(\frac{\sum_{i=1}^{n} P_{i, t} \times S_{i, t} \times T_{i, t}}{\sum_{i=1}^{n} P_{i, t} \times S_{i, t}}\right)
$$

where $T U R N_{k, t}$ is the market turnover for market $k$ in month $t$. The variable is detrended with the Hodrick-Prescott (HP) filter (Hodrick and Prescott 1997) by using a smoothing parameter $\lambda=14,400$, following the common practice in the literature to address the autocorrelation issue in $T U R N_{k, t}$.

\subsection{Market Volatility}

Finance literature suggests that trading volume is positively related to volatility because of the heterogeneous beliefs of investors in the presence of informational events (Karpoff 1987). Evidence also affirms a positive relationship between volatility and return in the real estate sector (Huang 2013). Therefore, market volatility had been routinely included in early studies as a control variable to account for market-wide common information flow (see, e.g., Bessembinder et al. 1996; Chuang and Lee 2006). The method by Statman et al. (2006) is used in this study to construct the measurement of market volatility as follows:

$$
V O L_{k, t}=\sum_{d=1}^{m} r_{k, d}{ }^{2}+2 \sum_{d=1}^{m} r_{k, d} r_{k, d-1}
$$

where $V O L_{k, t}$ is the market volatility of market $k$ in month $t, r_{k, d}$ is the market capitalization weighted average return of all REITs in market $k$ in day $d$, and $m$ is the total number of days in month $t$. Although the frequency of this time series is monthly, $V O L_{k, t}$ reflects the volatility of daily returns within a month.

\subsection{Market Dispersion}

When the monthly returns of REITs in a given market vary significantly among one another, investors face a high level of idiosyncratic risk (Statman et al. 2006). To hedge this idiosyncratic risk, investors need to rebalance their portfolios, subsequently generating additional trading activities, which is another important confounding factor that should be considered. The solution is to include the cross-sectional standard deviation of REIT returns (i.e., market dispersion) as another control variable (Bessembinder et al. 1996; Chuang and Lee 2006).

$$
\operatorname{DISP}_{k, t}=\sqrt{\frac{\sum_{i=1}^{n}\left(r_{i, t}-R E T_{k, t}\right)^{2} \times P_{i, t \times} S_{i, t}}{\sum_{i=1}^{n} P_{i, t} \times S_{i, t}}}
$$

where $D I S P_{k, t}$ is the market dispersion of market $k$ in month $t$. This market dispersion measurement is essentially the cross-sectional standard deviation of REIT monthly returns in a given market. Specifically, $R E T_{k, t}$ is used as the mean, and $\frac{P_{i, t} S_{i, t}}{\sum_{i=1}^{n} P_{i, t} \times S_{i, t}}$ is used as the value weighting in Equation (7). This approach is consistent with the calculation of market turnover and return.

The abovementioned transformations generate four variables for each REIT market, as summarized in Table 1. All 24 time series are stationary based on the augmented Dickey-Fuller (ADF) test and the Kwiatkowski-Phillips-Schmidt-Shin (KPSS) test. For the sake of brevity these test results are not reported but are available from the authors upon request.

Table 1 reveals a significant level of heterogeneity among the six REIT markets. First, the market turnover in South Korea is above $20 \%$ per month, which means that more than $20 \%$ of its outstanding 
shares are traded every month. The market is more active than the other four markets ${ }^{2}$. The same level of heterogeneity in terms of volatility and dispersion is also observed: market volatility varies between $1.40 \%$ (South Korea) and 0.09\% (Taiwan), and market dispersion ranges between 5.02\% (Singapore) and $1.68 \%$ (Taiwan). Therefore, the six markets significantly vary among all four measurements, with South Korea at the most volatile end and Taiwan being the most stable market. The data set offers an ideal setting to test the effect of overconfidence among different markets.

Table 1. Descriptive statistics in Asia Pacific REIT markets.

\begin{tabular}{|c|c|c|c|c|c|c|c|c|c|c|c|}
\hline \multirow[t]{2}{*}{ Market } & \multirow[t]{2}{*}{ From } & \multicolumn{2}{|l|}{$R E T$} & \multicolumn{2}{|c|}{$\begin{array}{l}\text { Turnover } \\
\text { (Raw) }\end{array}$} & \multicolumn{2}{|l|}{ TURN } & \multicolumn{2}{|l|}{$V O L$} & \multicolumn{2}{|l|}{$D I S P$} \\
\hline & & Mean & SD & Mean & SD & Mean & SD & Mean & SD & Mean & SD \\
\hline Singapore & July 2002 & $0.94 \%$ & $5.76 \%$ & $4.11 \%$ & $1.73 \%$ & $0.00 \%$ & $33.21 \%$ & $0.27 \%$ & $0.54 \%$ & $5.02 \%$ & $3.20 \%$ \\
\hline South Korea & May 2001 & $0.89 \%$ & $10.85 \%$ & $20.21 \%$ & $29.86 \%$ & $0.00 \%$ & $78.26 \%$ & $1.40 \%$ & $2.59 \%$ & $3.17 \%$ & $4.14 \%$ \\
\hline Taiwan & July 2006 & $0.53 \%$ & $3.26 \%$ & $1.30 \%$ & $1.32 \%$ & $0.00 \%$ & $67.19 \%$ & $0.09 \%$ & $0.32 \%$ & $1.68 \%$ & $1.17 \%$ \\
\hline Hong Kong & December 2005 & $0.94 \%$ & $5.67 \%$ & $5.77 \%$ & $6.00 \%$ & $0.00 \%$ & $34.40 \%$ & $0.28 \%$ & $0.52 \%$ & $3.46 \%$ & $2.70 \%$ \\
\hline Japan & September 2001 & $0.93 \%$ & $6.58 \%$ & $11.78 \%$ & $8.28 \%$ & $0.00 \%$ & $34.93 \%$ & $0.52 \%$ & $1.41 \%$ & $4.10 \%$ & $2.58 \%$ \\
\hline Australia & May 1994 & $0.62 \%$ & $6.37 \%$ & $3.67 \%$ & $2.14 \%$ & $0.00 \%$ & $23.57 \%$ & $0.36 \%$ & $0.84 \%$ & $4.88 \%$ & $7.99 \%$ \\
\hline
\end{tabular}

Note: This table reports the descriptive statistics of market return (RET), market turnover (Turnover and TURN), market volatility $(V O L)$, and market dispersion (DISP) for the six REIT markets. TURN is the detrended log turnover. All data are collected from Datastream, a financial database with over 35 million individual indicators across all major asset classes across 175 countries.

A VAR model is estimated to capture the dynamic process of endogenous variables (i.e., TURN and RET) while controlling for other conditions (i.e., VOL and DISP). The coefficients are estimated by iterated seemingly unrelated regression, which uses three-stage estimation for systems of simultaneous equations. For each of the six markets considered, the following equation is estimated:

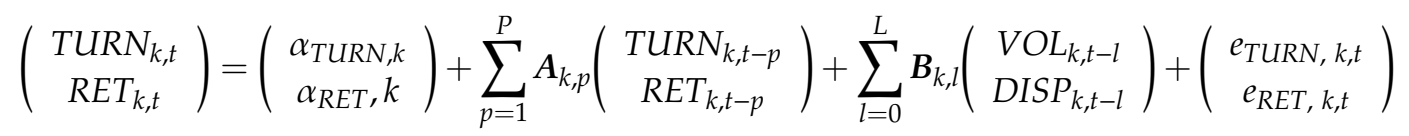

where $\alpha_{T U R N, k}$ and $\alpha_{R E T, k}$ are the intercepts, $e_{T U R N, k, t}$ and $e_{R E T, k, t}$ are the disturbance terms, $A_{k, p}$ and $\boldsymbol{B}_{k, l}$ are the coefficient matrices, $P$ and $L$ are the maximum lag length for endogenous and exogenous variables, and $k=1,2, \ldots, 6$ for each of the six REIT markets.

\section{Empirical Findings and Discussion}

We determine the lag order (i.e., the value of $P$ and $L$ ) based on the Akaike information criterion (AIC) and the Schwarz information criterion (SIC). In our final models, $P=1$ and $L=1$ for all countries, except for Japan, for which $P=2$ and $L=1$. We include the contemporary terms of $V O L$ and DISP in all VAR models as suggested by existing evidence in the literature (see, e.g., Huang 2013; Statman et al. 2006). Table 2 summarizes the details of VAR estimation results. All models pass the Chi-squared test at the $1 \%$ level, indicating the models fit the data well. The coefficient loadings of the two control variables are significant with expected signs in most of the markets. For instance, market volatility $(V O L)$ has a positive and contemporaneous impact on market turnover (TURN) in South Korea, Taiwan, Japan, and Hong Kong REIT markets. A similar pattern is also detected between market dispersion (DISP) and market turnover (TURN) in South Korea, Taiwan, and Japan REIT markets. These findings offer general support to certain alternative explanations of return-turnover relationship (i.e., heterogeneous beliefs and portfolio rebalancing), which is consistent with existing findings in the trading volume literature (see, e.g., Karpoff 1987).

2 In comparison, the monthly market turnover in the UK and the US is $7.81 \%$ and $13.2 \%$ over the same period, respectively. The two numbers are calculated using the same approach as the 6 sample economies, with raw data downloaded from Datastream. 
Table 2. Vector autoregression (VAR) model estimation results.

\begin{tabular}{|c|c|c|c|c|c|c|c|c|c|c|c|c|c|}
\hline \multirow{3}{*}{\multicolumn{2}{|c|}{$\begin{array}{c}\text { Market } \\
\text { Sample Period } \\
\text { Dependent Variable }\end{array}$}} & \multirow{2}{*}{\multicolumn{2}{|c|}{$\begin{array}{c}\text { South Korea } \\
\text { 2001M6-2015M4 }\end{array}$}} & \multicolumn{2}{|c|}{ Taiwan } & \multicolumn{2}{|c|}{ Singapore } & \multicolumn{2}{|c|}{ Australia } & \multicolumn{2}{|c|}{ Hong Kong } & \multicolumn{2}{|c|}{ Japan } \\
\hline & & & & \multicolumn{2}{|c|}{ 2006M8-2015M4 } & \multicolumn{2}{|c|}{ 2002M9-2015M4 } & \multicolumn{2}{|c|}{ 1994M6-2015M4 } & \multicolumn{2}{|c|}{ 2006M1-2015M4 } & \multicolumn{2}{|c|}{ 2001M10-2015M4 } \\
\hline & & TURN $_{t}$ & \multirow{2}{*}{$\begin{array}{c}\boldsymbol{R E T _ { \boldsymbol { t } }} \\
-0.029^{* * *}\end{array}$} & TURN $_{t}$ & $R E T_{t}$ & TURN $_{t}$ & $R E T_{t}$ & TURN $_{t}$ & $R E T_{t}$ & TURN $_{t}$ & $R E T_{t}$ & TURN $_{t}$ & $R E T_{t}$ \\
\hline \multirow{8}{*}{ 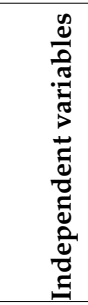 } & $T_{U R N_{t-1}}$ & $0.291 * * *$ & & $0.303 * * *$ & -0.001 & 0.096 & -0.004 & $0.244^{* * *}$ & 0.018 & $0.213^{* * *}$ & 0.022 & $0.248 * * *$ & 0.015 \\
\hline & $T U R N_{t-2}$ & - & - & - & - & - & - & - & - & - & - & $0.161^{* *}$ & -0.013 \\
\hline & $R E T_{t-1}$ & $1.265^{* * *}$ & -0.00003 & $3.762 * *$ & $0.231^{* * *}$ & $1.138^{* *}$ & $0.266^{* * *}$ & -0.232 & -0.025 & 0.089 & -0.124 & $0.883 * *$ & 0.083 \\
\hline & $R E T_{t-2}$ & - & - & - & - & - & - & - & - & - & - & $0.556^{*}$ & -0.038 \\
\hline & $V O L_{t}$ & $8.766^{* * *}$ & $0.898^{* *}$ & 24.391 * & $-1.826^{* *}$ & 5.774 & $-5.809 * * *$ & 1.419 & $-3.742 * * *$ & $16.542 * * *$ & $-6.581 * * *$ & $3.251 * *$ & $-2.751^{* * *}$ \\
\hline & $V O L_{t-1}$ & $8.118^{* * *}$ & $-0.848^{* * *}$ & 9.406 & $-3.444^{* * *}$ & 9.609 & $3.212 * * *$ & 2.599 & 0.249 & -6.291 & 1.818 & 2.851 & 0.037 \\
\hline & $D I S P_{t}$ & $4.870^{* * *}$ & 0.352 & $10.798^{* *}$ & $1.054^{* * *}$ & 1.152 & $0.542^{* * *}$ & -0.083 & $0.549^{* * *}$ & 1.764 & 0.346 & $4.117^{* * *}$ & $1.070^{* * *}$ \\
\hline & $\operatorname{DISP}_{t-1}$ & -1.318 & -0.195 & -0.079 & -0.317 & 0.092 & -0.065 & 0.006 & 0.061 & 0.327 & 0.014 & $-3.086^{* * *}$ & -0.063 \\
\hline \multirow{3}{*}{\multicolumn{2}{|c|}{$\begin{array}{c}\text { Chi-square } \\
\text { R-squared } \\
\text { AIC }\end{array}$}} & $128.612^{* * *}$ & $23.986^{* * *}$ & $47.412^{* * *}$ & $35.708^{* * *}$ & $22.661^{* * *}$ & $63.283^{* * *}$ & $23.948^{* * *}$ & $187.767^{* * *}$ & $26.502^{* * *}$ & $48.745^{* * *}$ & $93.895^{* * *}$ & $78.426^{* * *}$ \\
\hline & & 0.437 & 0.126 & 0.313 & 0.256 & 0.131 & 0.295 & 0.087 & 0.429 & 0.193 & 0.305 & 0.368 & 0.328 \\
\hline & & -0.208 & & -2.779 & & -2.509 & & -3.259 & & -2.826 & & -2.815 & \\
\hline
\end{tabular}

Note: This table reports the full sample VAR estimation results of Equation $(8){ }^{*} p<0.1{ }^{* *} p<0.05$, and ${ }^{* * *} p<0.01$. 
We now focus on the TURN equations (i.e., equations with TURN as the dependent variable) to test our hypotheses. First, we identify significant overconfident trading behavior in four REIT markets, that is, South Korea, Taiwan, Singapore, and Japan. In the TURN equations, the estimated coefficient for the lagged terms of $R E T$ are all positive and significant, after market volatility and dispersion are controlled, which suggests that previous market gains prompt investors to trade aggressively in the current month due to overconfidence. We find evidence to support Hypothesis 1 in four out of the six Asia Pacific markets considered.

To test Hypothesis 2, we first use the 2014 Jones Lang LaSalle (JLL) Global Real Estate Transparency Index to rank the six markets by the level of transparency (see Table 3). Australia is the most transparent market, followed by Singapore, Hong Kong, Japan, Taiwan, and South Korea. Coincidentally, South Korea and Taiwan are also the only two markets where short selling is not allowed (Bris et al. 2007). If Hypothesis 2 is true, then the effect of overconfidence (i.e., the coefficients of $R E T_{t-1}$ in the TURN equations) should be the largest for South Korea and Taiwan. Our findings offer strong support to this hypothesis. The estimated $R E T_{t-1}$ coefficient for South Korea (1.265) is larger than that for Singapore (1.138) and Japan (0.883). In the Taiwan REIT market, the estimated $R E T_{t-1}$ coefficient (3.762) is almost triple of that in South Korea.

Table 3. Jones Lang LaSalle (JLL) Transparency Index.

\begin{tabular}{lccc}
\hline \multicolumn{1}{c}{ Market } & 2014 Composite Score & 2014 Global Ranking & Transparency Level \\
\hline Australia & 1.36 & 3 & $\mathrm{H}$ \\
Singapore & 1.81 & 13 & $\mathrm{~T}$ \\
Hong Kong & 1.87 & 14 & $\mathrm{~T}$ \\
Japan & 2.22 & 26 & $\mathrm{~T}$ \\
Taiwan & 2.55 & 29 & $\mathrm{~S}$ \\
South Korea & 2.90 & 43 & $\mathrm{~S}$ \\
\hline
\end{tabular}

Note: H denotes highly transparent; T denotes transparent; and $\mathrm{S}$ denotes semi-transparent. Transparency scores are ranked from 1 (most transparent) to 5 (opaque).

We do not identify any overconfidence effect in the REIT markets of Australia and Hong Kong. This is probably due to the strong presence of institutional investors in these two countries. Behavioral studies suggest that individual investors are more prone to overconfidence than institutional ones (Chuang and Susmel 2011). As such, the overconfidence effect should be weak in markets dominated by institutional investors. The Australian REIT market has the largest market capitalization among the Asia Pacific REIT markets, and Hong Kong enjoys a well-established international financial market. Both economies rank very high in terms of market openness, which also significantly attracts institutional investors. ${ }^{3}$ Therefore, it is not surprising that Australia and Hong Kong have an insignificant return-turnover relationship.

To offer further support to Hypotheses 1 and 2, we estimate the impulse response function (IRF) from our VAR models to trace the effect of residual shock on endogenous variables over time. We use the generalized IRF by Koop et al. (1996) and Pesaran and Shin (1998) to estimate the influence of a one-standard deviation $(S D)$ innovation on endogenous variables over time. Figure 2 depicts the IRF of each market after a one-SD return innovation with the confidence bands of two standard errors.

3 Both Hong Kong and Australia rank high in the ICC Open Market Index (https://iccwbo.org/content/uploads/sites/3/2017/01/ ICCs-OPEN-MARKETS-INDEX-3RD-EDITION-2015.pdf). 
Australia

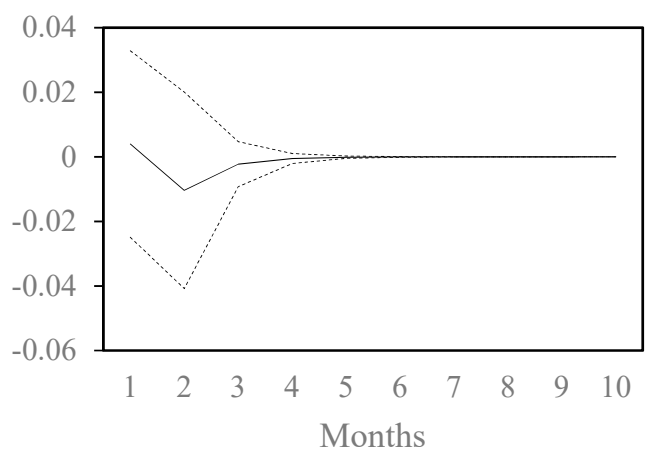

Singapore

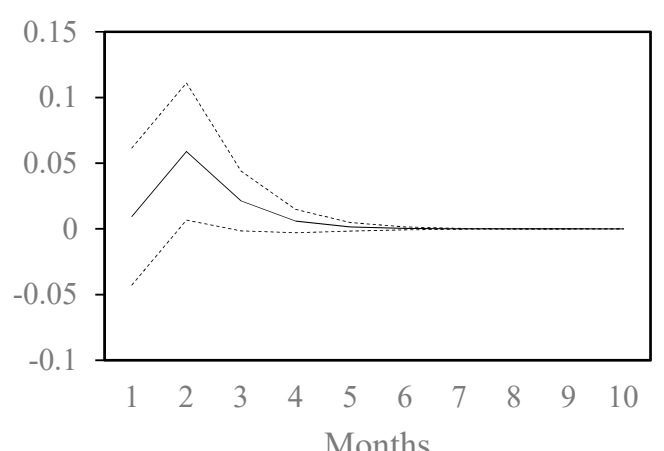

Hong Kong

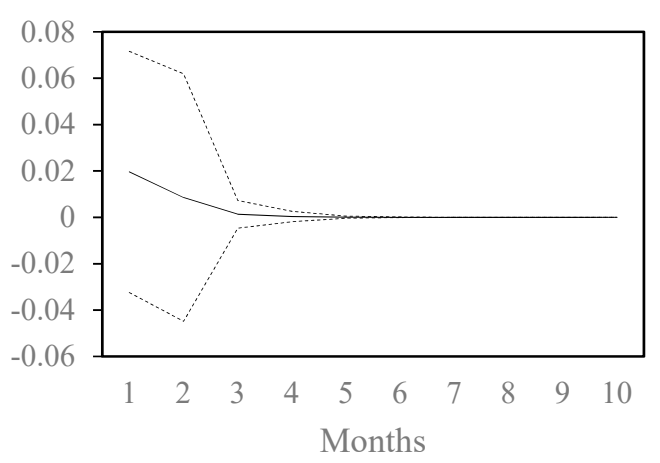

South Korea

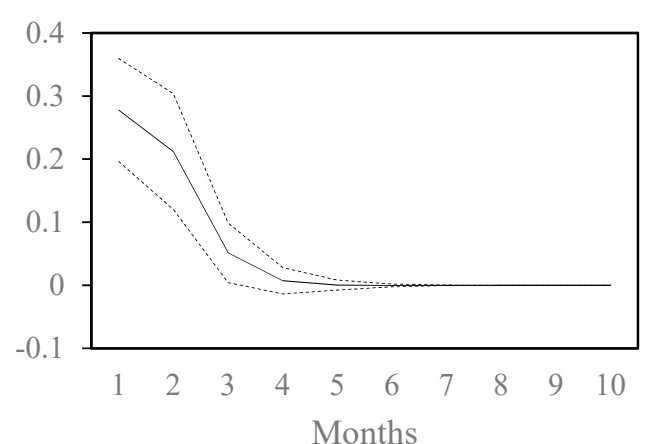

Japan

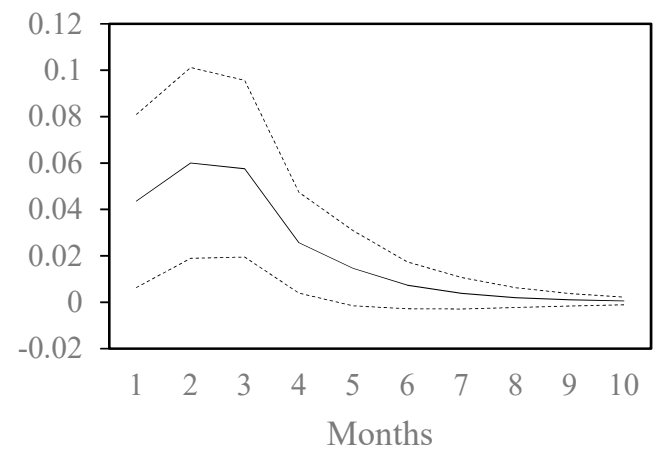

Taiwan

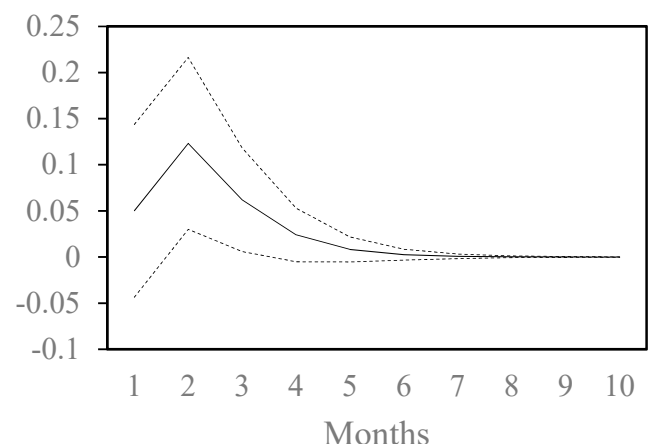

Figure 2. Impulse response functions (IRFs) of TURN to RET with two standard error bands. Note: For each market, the solid line is the impulse response function of TURN to RET following a one-SD RET innovation; the two dashed lines are the confidence bands of two standard errors. 
South Korea has the strongest overconfident trading in the months following return shocks. The market has an immediate turnover response in the first month, which falls dramatically in the next two months. Meanwhile, inverse U-shaped IRFs are identified in Japan, Singapore, and Taiwan REIT markets, where the second month sees the largest turnover response, indicating that investors take time to learn from previous trading performance and establish the overconfidence in their ability gradually. This argument conforms to the self-learning model suggested by Gervais and Odean (2001).

The turnover responses of South Korea, Japan, Taiwan, and Singapore over the six-month period following return shocks are $0.55 S D, 0.209 S D, 0.27 S D$, and 0.097SD, respectively. Consistent with the highest significant return-turnover relation in VAR results, South Korea has the highest accumulated response among other REIT markets, which is in line with our VAR analysis in Table 1 where significant overconfidence effect is identified in these markets. The turnover response of the REIT markets in Australia and Hong Kong is not significantly different from 0 over the 10 months following the return shocks. These findings further support Hypotheses 1 and 2.

We now estimate Equation (8) with two sub-samples to test Hypothesis 3, that is, whether the overconfident trading behavior is stronger in bull markets. Although the global financial crisis serves as a natural setting to test this hypothesis, the six REIT markets respond to the event differently. For instance, recovery (i.e., the cutoff point between the up- and down-markets) started from October 2008 in South Korea, Hong Kong, Taiwan, and Japan, whereas it started in March 2009 for Singapore and Australia. We choose the May 2013 to June 2014 period to be the down-market period for Taiwan because data in this period are more recent and reliable than those in the June 2007 to October 2008 period, when the Taiwan REIT market was still in its infancy stage. In Figure 3, we plot the daily value-weighted price indices and the choice of the up- and down-market sub-sample periods in each of the six markets ${ }^{4}$. Equation (8) is re-estimated by using the down- and up-market sub-samples, and the results are provided in Table 4 . For each independent variable, we report its coefficient estimates in the up- and down-markets together to facilitate comparison.

Consistent with the findings in Table 2, we did not identify any overconfidence effect in the REIT markets of Australia and Hong Kong. The coefficient estimates of $R E T_{t-1}$ are significant and positive in the up-market period in South Korea, Taiwan, Singapore, and Japan REIT markets but insignificant in the down-market period for all countries. Therefore, the findings from the sub-period analysis provide support to Hypothesis 3 . The sub-sample analysis reveals that the overconfidence effect on trading volume only exists in the up-market.

To further illustrate the effect of overconfidence on trading volume, we feed a positive return signal to the IRF functions of markets with significant overconfident effect (i.e., South Korea, Singapore, Taiwan, and Japan) and simulate the responses of TURN (i.e., trading volume) in the following three and six months. The positive return shock is calculated by taking the average of all positive month-to-month changes in RET during the sampling period. This average monthly positive return is a representative estimation of positive return shocks in each market and captures the notation that the return from the previous month can be viewed as a reference point that may affect trading strategies in the following months.

4 The value-weighted price indices are calculated by using Equation (3). The base period (index = 100) is 30 April 2015 for all markets. 
Australia

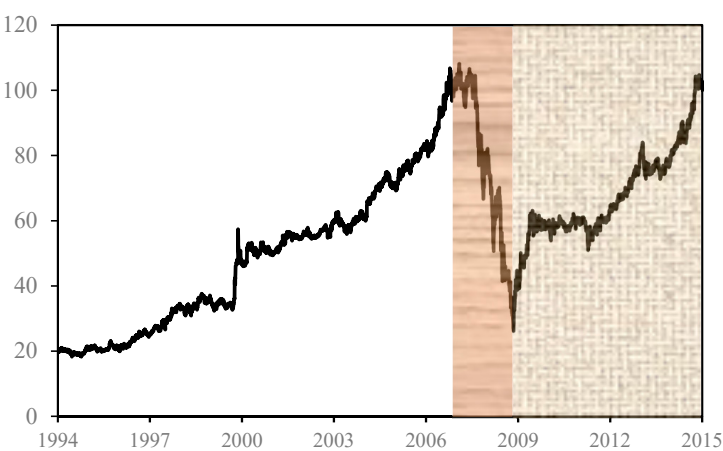

Singapore

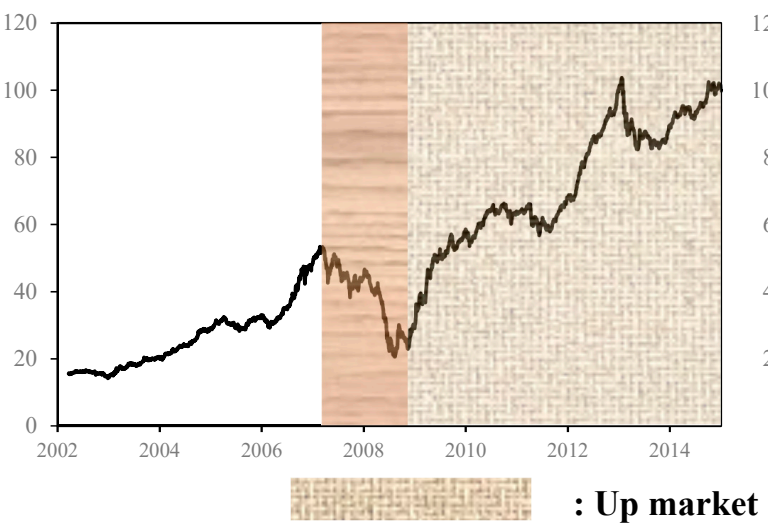

Hong Kong

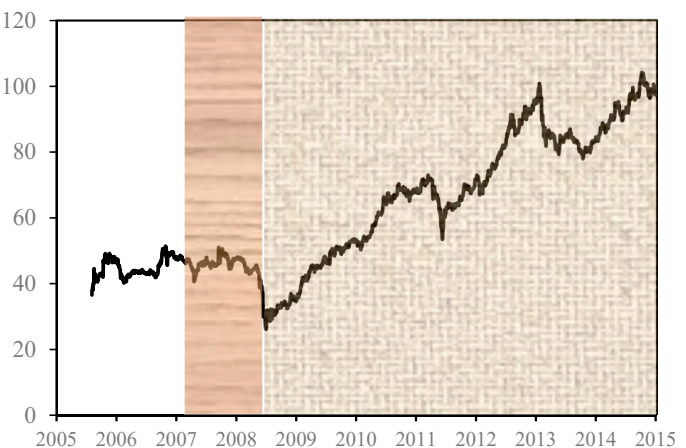

South Korea

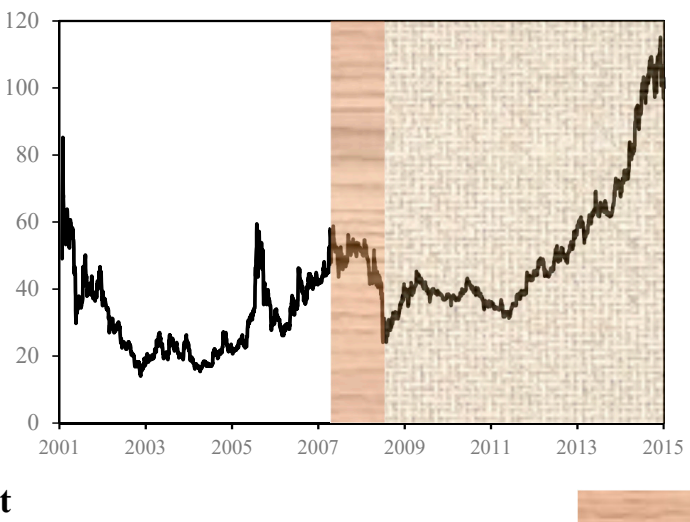

Japan

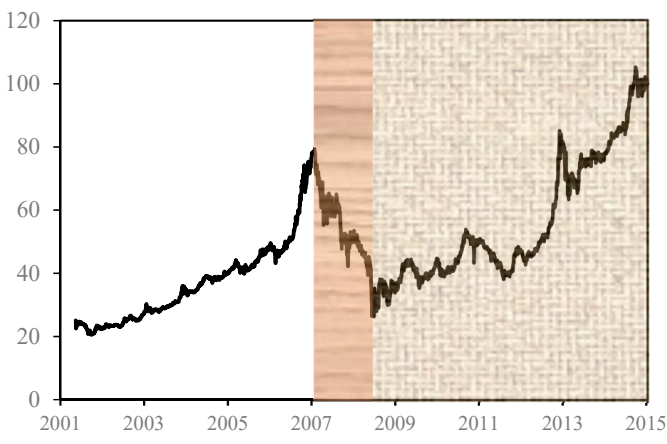

Taiwan

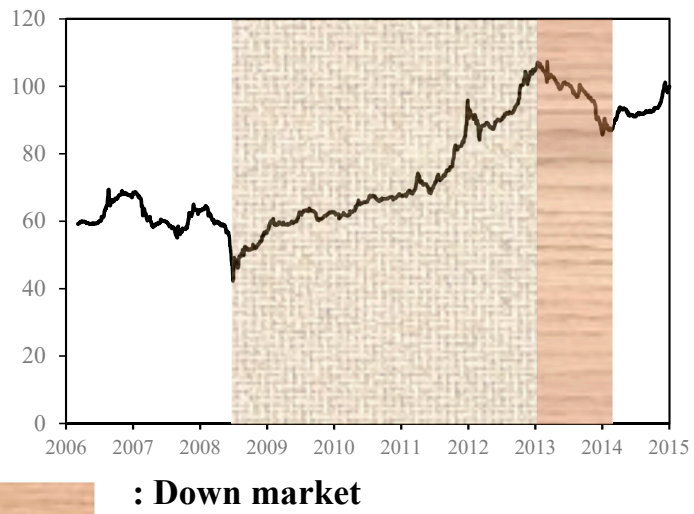

Figure 3. Definition of up- and down-markets. The value-weighted price indices are calculated by using Equation (2). The base period (index $=100)$ is 30 April 2015 for all markets. 
Table 4. Sub-period VAR results.

\begin{tabular}{|c|c|c|c|c|c|c|c|c|c|c|c|c|c|c|}
\hline \multicolumn{3}{|c|}{ Market } & \multicolumn{2}{|c|}{ South Korea } & \multicolumn{2}{|c|}{ Taiwan } & \multicolumn{2}{|c|}{ Singapore } & \multicolumn{2}{|c|}{ Australia } & \multicolumn{2}{|c|}{ Hong Kong } & \multicolumn{2}{|c|}{ Japan } \\
\hline \multicolumn{3}{|c|}{ Down Market Period } & \multicolumn{2}{|c|}{$\begin{array}{l}\text { September 2007- } \\
\text { October } 2008\end{array}$} & \multicolumn{2}{|c|}{$\begin{array}{l}\text { May 2013- } \\
\text { June 2014 }\end{array}$} & \multicolumn{2}{|c|}{$\begin{array}{l}\text { June 2007- } \\
\text { March 2009 }\end{array}$} & \multicolumn{2}{|c|}{$\begin{array}{l}\text { June 2007- } \\
\text { March 2009 }\end{array}$} & \multicolumn{2}{|c|}{$\begin{array}{l}\text { June 2007- } \\
\text { October } 2008\end{array}$} & \multicolumn{2}{|c|}{$\begin{array}{c}\text { July 2007- } \\
\text { October } 2008\end{array}$} \\
\hline \multicolumn{3}{|c|}{ Up Market Period } & \multicolumn{2}{|c|}{$\begin{array}{l}\text { November 2008- } \\
\text { April } 2015\end{array}$} & \multicolumn{2}{|c|}{$\begin{array}{c}\text { November 2008- } \\
\text { April } 2013\end{array}$} & \multicolumn{2}{|c|}{$\begin{array}{l}\text { April 2009- } \\
\text { April 2015 }\end{array}$} & \multicolumn{2}{|c|}{$\begin{array}{l}\text { April 2009- } \\
\text { April } 2015\end{array}$} & \multicolumn{2}{|c|}{$\begin{array}{c}\text { November 2008- } \\
\text { April } 2015\end{array}$} & \multicolumn{2}{|c|}{$\begin{array}{l}\text { November 2008- } \\
\text { April } 2015\end{array}$} \\
\hline Depe & dent Varial & & TURN $_{t}$ & $R E T_{t}$ & TURN $_{t}$ & $R E T_{t}$ & TURN $_{t}$ & $R E T_{t}$ & $T_{U R N_{t}}$ & $R E T_{t}$ & TURN $_{t}$ & $R E T_{t}$ & TURN $_{t}$ & $R E T_{t}$ \\
\hline \multirow{7}{*}{ 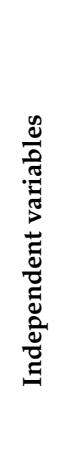 } & TURN $_{t-1}$ & Down Market: & -0.171 & $-0.042 * *$ & 0.182 & $0.031^{* *}$ & $0.510^{* * *}$ & $0.171^{* * *}$ & 0.112 & -0.038 & 0.232 & 0.046 & 0.147 & 0.066 \\
\hline & & Up Market: & $0.474^{* * *}$ & 0.001 & $0.388^{* * *}$ & -0.003 & $0.308^{* * *}$ & -0.027 & $0.371^{* * *}$ & -0.013 & 0.112 & 0.014 & $0.406^{* * *}$ & $0.040 *$ \\
\hline & $R E T_{t-1}$ & $\begin{array}{l}\text { Down Market: } \\
\text { Up Market: }\end{array}$ & $\begin{array}{l}-4.248 \\
2.217^{* *}\end{array}$ & $\begin{array}{l}-0.115 \\
-0.157\end{array}$ & $\begin{array}{l}2.173 \\
4.145^{* *}\end{array}$ & $\begin{array}{l}-0.580 \text { ** } \\
0.034\end{array}$ & $\begin{array}{l}-0.232 \\
1.815^{* * *}\end{array}$ & $\begin{array}{l}0.089 \\
-0.186\end{array}$ & $\begin{array}{l}-0.178 \\
-0.226\end{array}$ & $\begin{array}{l}-0.330 \\
-0.180\end{array}$ & $\begin{array}{l}-0.533 \\
0.960\end{array}$ & $\begin{array}{l}-0.280 \\
-0.186\end{array}$ & $\begin{array}{l}-0.977 \\
1.427 * * *\end{array}$ & $\begin{array}{l}-0.340 \\
0.126\end{array}$ \\
\hline & $V O L_{t}$ & $\begin{array}{l}\text { Down Market: } \\
\text { Up Market: }\end{array}$ & $\begin{array}{l}44.731^{* * *} \\
3.465\end{array}$ & $\begin{array}{l}4.379^{* * *} \\
-1.001 * * *\end{array}$ & $\begin{array}{l}138.834 \\
59.016\end{array}$ & $\begin{array}{l}-21.168^{* * *} \\
1.263\end{array}$ & $\begin{array}{l}0.978 \\
-3.923\end{array}$ & $\begin{array}{l}-4.564^{* * *} \\
0.606\end{array}$ & $\begin{array}{l}0.396 \\
4.994\end{array}$ & $\begin{array}{l}-1.091 \\
-3.597 * *\end{array}$ & $\begin{array}{l}9.860 \\
43.324 * *\end{array}$ & $\begin{array}{l}-6.801 * * * \\
-4.609 *\end{array}$ & $\begin{array}{l}2.597^{*} \\
7.303\end{array}$ & $\begin{array}{l}-3.011^{\text {***}} \\
-1.740\end{array}$ \\
\hline & $V O L_{t-1}$ & $\begin{array}{l}\text { Down Market: } \\
\text { Up Market: }\end{array}$ & $\begin{array}{l}49.270^{* * *} \\
4.137\end{array}$ & $\begin{array}{l}0.917 \\
-1.566^{* * *}\end{array}$ & $\begin{array}{l}71.519 \\
3.454\end{array}$ & $\begin{array}{l}-17.559^{* *} \\
-4.867^{* * *}\end{array}$ & $\begin{array}{l}-6.303 \\
23.856^{* * *}\end{array}$ & $\begin{array}{l}2.948^{*} \\
1.110\end{array}$ & $\begin{array}{l}3.121 \\
-1.195\end{array}$ & $\begin{array}{l}-0.955 \\
1.100\end{array}$ & $\begin{array}{l}21.68 \\
-0.570\end{array}$ & $\begin{array}{l}0.774 \\
1.578\end{array}$ & $\begin{array}{l}12.600^{* *} \\
2.379\end{array}$ & $\begin{array}{l}-1.588 \\
-0.183\end{array}$ \\
\hline & $\operatorname{DISP}_{t}$ & $\begin{array}{l}\text { Down Market: } \\
\text { Up Market: }\end{array}$ & $\begin{array}{l}-2.637 \\
5.204^{* * *}\end{array}$ & $\begin{array}{l}-0.411 \\
0.799 * * *\end{array}$ & $\begin{array}{l}7.708 \\
11.132 *\end{array}$ & $\begin{array}{l}-0.156 \\
1.471^{* * *}\end{array}$ & $\begin{array}{l}1.626 \\
1.641\end{array}$ & $\begin{array}{l}0.639 \\
0.896^{* * *}\end{array}$ & $\begin{array}{l}3.736^{*} \\
0.095\end{array}$ & $\begin{array}{l}-2.119 \\
0.892 * * *\end{array}$ & $\begin{array}{l}4.188 \\
-0.390\end{array}$ & $\begin{array}{l}0.435 \\
0.218\end{array}$ & $\begin{array}{l}-6.214^{*} \\
5.390^{* * *}\end{array}$ & $\begin{array}{l}2.508^{*} \\
1.281^{* * *}\end{array}$ \\
\hline & $D I S P_{t-1}$ & $\begin{array}{l}\text { Down Market: } \\
\text { Up Market: }\end{array}$ & $\begin{array}{l}-1.013 \\
-2.275\end{array}$ & $\begin{array}{l}0.168 \\
-0.243\end{array}$ & $\begin{array}{l}-3.253 \\
-7.144\end{array}$ & $\begin{array}{l}0.099 \\
-0.154\end{array}$ & $\begin{array}{l}2.061 \\
-2.475 *\end{array}$ & $\begin{array}{l}-0.746 \\
0.460 *\end{array}$ & $\begin{array}{l}-2.749 \\
0.102\end{array}$ & $\begin{array}{l}1.416 \\
0.109\end{array}$ & $\begin{array}{l}-8.841 * \\
0.278\end{array}$ & $\begin{array}{l}-1.103 \\
0.066\end{array}$ & $\begin{array}{l}-2.110 \\
-6.285 \text { *** }\end{array}$ & $\begin{array}{l}0.981 \\
-0.132\end{array}$ \\
\hline
\end{tabular}

Note: ${ }^{*} p<0.1,{ }^{* *} p<0.05$, and ${ }^{* * *} p<0.01$. The down- and the up-market periods are different for the six markets. For South Korea, the down-market and the up-market is from September 2007 to October 2008, and from November 2008 to April 2015, respectively. For Taiwan, the down-market and the up-market is from May 2013 to June 2014 and from November 2008 to April 2013, respectively. For Singapore, the down-market and the up-market are from June 2007 to March 2009 and from April 2009 to April 2015 , respectively. For Australia, the down-market and the up-market are from June 2007 to March 2009 and from April 2009 to April 2015, respectively. For Hong Kong, the down-market and the up-market are from June 2007 to October 2008 and from November 2008 to April 2015, respectively. For Japan, the down-market and the up-market are from July 2007 to October 2008 and from November 2008 to April 2015, respectively. 
Table 5 shows that the South Korea REIT market has the largest average positive return increase $(10.62 \%)$, followed by the REIT markets of Japan (5.96\%), Singapore $(5.14 \%)$, and Taiwan $(3.08 \%)$. The initial response to this positive return shock is rather large in certain markets. For instance, the overall trading volume is estimated to increase by $41.53 \%$ and $14.92 \%$ in the subsequent three months in the South Korea and Taiwan REIT markets, respectively. Meanwhile, the response in the Singapore and Japan REIT markets is mild. When the investigation window is extended to six months, the response of the trading volume increases only marginally across all four markets. This finding is consistent with the patterns identified in Figure 2, where overconfident trading mainly occurs within the first three months following the return shocks.

Table 5. Trading volume responses to positive return shocks.

\begin{tabular}{lcccc}
\hline \multicolumn{1}{c}{ Markets } & South Korea & Taiwan & Singapore & Japan \\
\hline Average positive returns & $10.62 \%$ & $3.08 \%$ & $5.14 \%$ & $5.96 \%$ \\
Trading volume changes-3 months & $41.53 \%$ & $14.92 \%$ & $2.64 \%$ & $5.12 \%$ \\
Trading volume changes-6 months & $42.15 \%$ & $17.14 \%$ & $2.88 \%$ & $6.61 \%$ \\
\hline
\end{tabular}

\section{Robustness Check}

In Section 4, the variable DISP is the cross-sectional value-weighted standard deviation of REIT returns following Statman et al. (2006). An alternative measurement is the mean absolute cross-sectional return deviation (MAD) as in Bessembinder et al. (1996) and Chuang and Lee (2006).

$$
M A D_{t}=\sum_{i=1}^{n}\left|r_{i t}-R E T_{t}\right| \frac{P_{i t} S_{i t}}{\sum_{j=1}^{n} P_{j t} S_{j t}}
$$

The variable $V O L$ uses the raw daily return of each month only (French et al. 1987). We also considered squared residuals, generalized autoregressive conditional heteroscedasticity (GARCH) filters, and asymmetric GARCH filters as alternative measurements of VOL. Specifically, the daily value-weighted return of each REIT market is used to fit an autoregressive (AR) model, and then squared daily residuals are cumulated into monthly volatility, as suggested by Griffin et al. (2007). The monthly volatility generated with this approach is named ARVOL. To generate the GARCH estimator of volatility (GARCHVOL hereafter), we used a GARCH $(1,1)$ model as specified in Equations (10) and (11) below.

$$
\begin{gathered}
r_{t}=\phi(L) r_{t}+\varepsilon_{t}, \quad \varepsilon_{t} \sim N\left(0, \sigma_{t}^{2}\right) \\
\sigma_{t}^{2}=\alpha_{0}+\alpha_{1} \varepsilon_{t-1}{ }^{2}+\beta_{1} \sigma_{t-1}{ }^{2}
\end{gathered}
$$

where $r_{t}$ is the daily value-weighted market return and $\phi(L)$ is the lag operator.

In a stock market, a negative return evidently influences volatility more than a positive return with the same magnitude. The TGARCH model is designed to capture this asymmetric effect (Glosten et al. 1993). Specifically, this model modifies the GARCH model by adding a TARCH term to the conditional variance, and extending Equations (11) and (12) as follows:

$$
\sigma_{t}^{2}=\alpha_{0}+\alpha_{1} \varepsilon_{t-1}^{2}+\gamma_{1} I_{t-1} \varepsilon_{t-1}^{2}+\beta_{1} \sigma_{t-1}^{2}
$$

where $I_{t-1}$ is the indicator function that is equal to 1 if $\varepsilon_{t-1}<0$, and 0 otherwise.

Although the TGARCH model is an extension of the GARCH model, a REIT market may not have the asymmetric effect. Therefore, the TGARCH model is only used when the estimated coefficient of $\gamma_{1}$ is significant in Equation (12), e.g., for South Korea, Singapore, Australia, and Japan REIT markets only. The newly generated variable under TGARCH, if used in the estimation, is then named TGARCHVOL. 
Three pairs of alternative control variables (ARVOL-MAD, GARCHVOL-MAD, and TGARCHVOL$\mathrm{MAD}$ ) are generated to re-estimate the VAR model in Section 4 (i.e., the baseline model as illustrated in Table 2). Table 6 contrasts the coefficient estimates of RET, VOL, and DISP between the three alternative approaches and the baseline model in Panels A, B, and C, respectively. Panel D of Table 6 shows the model summary (e.g., AR lag and GARCH terms significant at the $1 \%$ level).

Panel A shows that the overconfidence effects of the six REIT markets are insensitive to the choice of volatility and dispersion measures. The overconfident trading behavior is still significant in Singapore, South Korea, Taiwan, and Japan but insignificant in Hong Kong and Australia. For each of the four markets with the overconfidence effect, the magnitude of the lagged return coefficients is similar between the baseline and the alternative models. The three alternative models offer consistent support to Hypotheses 1 and 2.

Further evidence of the robustness of our results can be found in Panels B and C, where the coefficient estimates of VOL and DISP are highly consistent between the baseline and the alternative models. The magnitude of the coefficient estimates of $V O L$ significantly differs among the models, which is an expected result of the different volatility measures.

In addition to the full-sample VAR estimation, we also conduct IRF analysis using alternative measures. To save space, we only summarize the value of IRF over different periods in Table 7 . Consistent with the results in Figure 2, the confidence bands in the Australia and Hong Kong REIT markets do not suggest an IRF that is significantly different from zero. Therefore, we report the four markets with a significant turnover response to market return shocks only. Specifically, Table 7 indicates the IRF in South Korea, Taiwan, Japan, and Singapore only. Overall, the turnover response to return patterns is similar among the three IRF versions in all four REIT markets and, importantly, consistent with the patterns identified in Figure 2. 
Table 6. VAR full-sample results in different measures of market volatility and dispersion.

\begin{tabular}{|c|c|c|c|c|c|c|c|}
\hline & South Korea & Taiwan & Singapore & Australia & Hong Kong & & pan \\
\hline \multicolumn{8}{|c|}{ Panel A: Lagged RET Coefficient on TURN } \\
\hline & First lag & First lag & First lag & First lag & First lag & First lag & Second lag \\
\hline ARVOL-MAD & $0.988^{* *}$ & $3.279 * *$ & $0.866^{*}$ & -0.358 & 0.023 & $0.826^{* *}$ & $0.604 * *$ \\
\hline GARCHVOL-MAD & $0.988^{* *}$ & $3.279^{* *}$ & $0.866^{*}$ & -0.358 & 0.023 & $0.826^{* *}$ & $0.604 * *$ \\
\hline TGARCHVOL-MAD & $0.920 * *$ & NA & 0.924 * & -0.365 & NA & $0.827 * *$ & $0.593 * *$ \\
\hline Baseline model & $1.265^{* * *}$ & $3.762^{* *}$ & $1.138^{* *}$ & -0.232 & 0.089 & $0.883^{* *}$ & 0.556 * \\
\hline \multicolumn{8}{|c|}{ Panel B: concurrent $V O L$ on TURN } \\
\hline ARVOL-MAD & $38.678^{* * *}$ & $100.508 *$ & 10.484 & 6.863 & $35.283 * * *$ & $9.885^{* * *}$ & \\
\hline GARCHVOL-MAD & $38.678^{* * *}$ & $100.508^{*}$ & 10.484 & 6.863 & $35.283^{* * *}$ & $9.885^{* * *}$ & \\
\hline TGARCHVOL-MAD & $43.805^{* * *}$ & NA & 14.352 & 5.944 & NA & $9.191 * * *$ & \\
\hline Baseline model & $8.766^{* * *}$ & $24.391 *$ & 5.774 & 1.419 & $16.542^{* * *}$ & $3.251^{* *}$ & \\
\hline \multicolumn{8}{|c|}{ Panel C: concurrent DISP on TURN } \\
\hline ARVOL-MAD & $4.914^{* * *}$ & $13.869 * * *$ & 1.897 & -0.165 & 1.761 & $5.434^{* * *}$ & \\
\hline GARCHVOL-MAD & $4.914^{* * *}$ & $13.869 * * *$ & 1.897 & -0.165 & 1.761 & $5.434^{* * *}$ & \\
\hline TGARCHVOL-MAD & $4.788^{* * *}$ & NA & 1.837 & -0.100 & NA & $5.442^{* * *}$ & \\
\hline Baseline model & $4.870^{* * *}$ & $10.798^{* *}$ & 1.152 & -0.083 & 1.764 & $4.117^{* * *}$ & \\
\hline $\mathrm{ARCH}$ terms significant & YES & YES & YES & YES & YES & YES & \\
\hline GARCH terms significant & YES & YES & YES & YES & YES & YES & \\
\hline TARCH terms significant & YES & $\mathrm{NO}$ & YES & YES & $\mathrm{NO}$ & YES & \\
\hline
\end{tabular}


Table 7. Robustness check of the impulse response function analysis.

\begin{tabular}{|c|c|c|c|c|c|c|c|c|c|}
\hline & & Month 1 & Month 2 & Month 3 & Month 4 & Month 5 & Month 6 & 3 Months & 6 Months \\
\hline \multirow[t]{3}{*}{ South Korea } & ARVOL-MAD & $24.50 \%$ & $20.20 \%$ & $7.30 \%$ & $2.50 \%$ & $0.90 \%$ & $0.30 \%$ & $52.00 \%$ & $55.70 \%$ \\
\hline & TGARCHVOL-MAD & $22.30 \%$ & $18.50 \%$ & $6.60 \%$ & $2.40 \%$ & $0.90 \%$ & $0.30 \%$ & $47.40 \%$ & $50.90 \%$ \\
\hline & Base model & $27.80 \%$ & $21.20 \%$ & $5.20 \%$ & $0.70 \%$ & $0.00 \%$ & $0.00 \%$ & $54.10 \%$ & $54.90 \%$ \\
\hline \multirow[t]{3}{*}{ Taiwan } & ARVOL-MAD & $5.30 \%$ & $11.30 \%$ & $5.70 \%$ & $2.20 \%$ & $0.70 \%$ & $0.20 \%$ & $22.30 \%$ & $25.50 \%$ \\
\hline & TGARCHVOL-MAD & $5.30 \%$ & $11.30 \%$ & $5.80 \%$ & $2.20 \%$ & $0.80 \%$ & $0.20 \%$ & $22.40 \%$ & $25.60 \%$ \\
\hline & Base model & $5.00 \%$ & $12.30 \%$ & $6.20 \%$ & $2.40 \%$ & $0.80 \%$ & $0.30 \%$ & $23.50 \%$ & $27.00 \%$ \\
\hline \multirow[t]{3}{*}{ Japan } & ARVOL-MAD & $5.80 \%$ & $6.00 \%$ & $5.90 \%$ & $2.30 \%$ & $1.30 \%$ & $0.70 \%$ & $17.70 \%$ & $22.00 \%$ \\
\hline & TGARCHVOL-MAD & $5.80 \%$ & $6.00 \%$ & $5.80 \%$ & $2.20 \%$ & $1.30 \%$ & $0.70 \%$ & $17.60 \%$ & $21.80 \%$ \\
\hline & Base model & $4.40 \%$ & $6.00 \%$ & $5.80 \%$ & $2.60 \%$ & $1.50 \%$ & $0.70 \%$ & $16.10 \%$ & $20.90 \%$ \\
\hline \multirow[t]{3}{*}{ Singapore } & ARVOL-MAD & $0.80 \%$ & $4.90 \%$ & $1.60 \%$ & $0.40 \%$ & $0.10 \%$ & $0.00 \%$ & $7.30 \%$ & $7.80 \%$ \\
\hline & TGARCHVOL-MAD & $1.20 \%$ & $5.30 \%$ & $1.50 \%$ & $0.30 \%$ & $0.10 \%$ & $0.00 \%$ & $8.00 \%$ & $8.30 \%$ \\
\hline & Base model & $0.90 \%$ & $5.90 \%$ & $2.10 \%$ & $0.60 \%$ & $0.20 \%$ & $0.00 \%$ & $9.00 \%$ & $9.70 \%$ \\
\hline
\end{tabular}

Notes: This table reports the IRF in each of the six months following one-standard deviation market return shock and the accumulated IRF over three- and six-month periods. 
Finally, we also assess the sensitivity of the sub-period results to alternative pairs of control variables. Table 8 compares the coefficient estimates of $R E T_{t-1}$ in the baseline model and alternative models. Evidently, different control variable measures do not change the conclusion regarding Hypothesis 3. Overall, the findings in Section 4 are robust and reliable.

Table 8. Robustness check of sub-period VAR results.

\begin{tabular}{lllllll}
\hline & South Korea & Taiwan & Singapore & Australia & Hong Kong & Japan \\
\hline AR-MAD & & & & & & \\
Down & 2.384 & 2.687 & -0.060 & -0.344 & -0.625 & -0.903 \\
Up & $3.358^{* * *}$ & 3.148 & $0.951^{*}$ & -0.148 & 0.323 & $1.388^{* * *}$ \\
\hline GARCH-MAD & & & & & & \\
Down & 2.384 & 2.687 & -0.060 & -0.344 & -0.625 & -0.903 \\
Up & $3.358^{* * *}$ & 3.148 & $0.951^{*}$ & -0.148 & 0.323 & $1.388^{* * *}$ \\
\hline TGARCH-MAD & & & & & & -0.882 \\
Down & $2.515^{* * *}$ & 2.685 & -0.059 & -0.332 & -0.634 & $1.367^{* * *}$ \\
Up & $3.433^{* * *}$ & 3.148 & $0.976^{*}$ & -0.116 & 0.287 & \\
\hline Base model & & & & & & $-0.977^{* *}$ \\
Down & -4.248 & 2.173 & -0.232 & -0.178 & -0.533 & $1.427^{* * *}$ \\
Up & $2.217^{* *}$ & $4.145^{* *}$ & $1.815^{* * *}$ & -0.226 & 0.960 & \\
\hline
\end{tabular}

Notes: This table shows the coefficient of $R E T_{t-1}$ in the baseline model. ${ }^{*} p<0.1,{ }^{* *} p<0.05$, and ${ }^{* * *} p<0.01$. The down- and the up-market periods are different for the six markets. For South Korea, the down-market and the up-market are from September 2007 to October 2008 and from November 2008 to April 2015, respectively. For Taiwan, the down-market and the up-market are from May 2013 to June 2014 and from November 2008 to April 2013, respectively. For Singapore, the down-market and the up-market are from June 2007 to March 2009 and from April 2009 to April 2015, respectively. For Australia, the down-market and the up-market are from June 2007 to March 2009 and from April 2009 to April 2015, respectively. For Hong Kong, the down-market and the up-market are from June 2007 to October 2008 and from November 2008 to April 2015, respectively. For Japan, the down-market and the up-market are from July 2007 to October 2008 and from November 2008 to April 2015, respectively.

\section{Conclusions}

Overconfidence manifests when investors attribute too much investment success to their investment ability, which subsequently causes investors to trade actively in the future. Empirical analysis often identifies the aggregate overconfidence effect through a positive lead-lag relationship between trading activity and previous market performance. In this study, we verify this relationship by using data from six Asia Pacific REIT markets. Our VAR estimation demonstrates that overconfidence causes excessive trading activities. In addition, the overconfidence effect is larger in inefficient market settings and is only present in up-markets. All results are robust to alternative measurements of the control variables.

Excessive trading caused by overconfidence negatively affects investment performance. Unfortunately, real estate markets are known to be a hot bed for behavioral anomalies and biases (see, e.g., Bao and Gong 2017; Bokhari and Geltner 2011; Liu et al. 2015), and overconfidence is no exception (Eichholtz and Yönder 2015; Tan 2017; Yung et al. 2015). Our study makes the first attempt to empirically verify the overconfidence effect in the REIT sector. The findings add value to the general overconfidence literature and provide valuable insights into the overconfidence effect in the REIT markets, where behavioral biases could be more prevalent. Our findings also have significant policy implications. Specifically, we found that market inefficiency amplifies the overconfidence effect, which is costly to both investors and the society. Such a finding is further evidence that market friction negatively affects investment performance by aggravating the overconfidence effect. Moreover, the overconfidence effect is only significant during up-markets. Policymakers and regulators should be cautious about the effects of overconfidence on market momentum during a market boom.

Our findings are consistent with the existing overconfidence literature and provide new information about the overconfidence effect in the Asia Pacific REIT markets. Nevertheless, the analysis is conducted on the aggregated, market level only. One way to extend this study is to evaluate the positive lead-lag 
relationship between trading activity and previous market performance on an individual level. For instance, one may obtain the profile and trading records of individual investors and then analyze whether and how investment gains affect trading activities in the future. Such an analysis could verify the overconfidence effect on a disaggregated level and reveal whether the investor's characteristics (i.e., demographic, social, or economic traits) moderate the overconfidence effect. Certainly, this type of analysis should use data from a small geographical region to reduce the effect of confounding factors, instead of adopting the multiple countries approach as in this study.

Author Contributions: H.X.H.B. contributed to conceptualization, funding acquisition, formal analysis, supervision, writing - review and editing. S.H.L. contributed to conceptualization, methodology, data curation, visualization, formal analysis, writing-Original Draft. All authors have read and agreed to the published version of the manuscript.

Funding: This research was funded by the Economic and Social Research Council (ESPC, Grant No. ES/P004296/1) and the National Natural Science Foundation of China (NNSFC, Grant No. 71661137009).

Conflicts of Interest: The authors declare no conflict of interest.

\section{References}

Bao, Helen X. H., and Cynthia Miao Gong. 2017. Reference-dependent analysis of capital structure and REIT performance. Journal of Behavioral and Experimental Economics 69: 38-49. [CrossRef]

Barber, Brad M., and Terrance Odean. 2000. Trading is hazardous to your wealth: The common stock investment performance of individual investors. Journal of Finance 55: 773-806. [CrossRef]

Barber, Brad M., and Terrance Odean. 2001. Boys will be boys: Gender, overconfidence, and common stock investment. Quarterly Journal of Economics 116: 261-92. [CrossRef]

Barber, Brad M., Yi-Tsung Lee, Yu-Jane Liu, and Terrance Odean. 2009. Just How Much Do Individual Investors Lose by Trading? Review of Financial Studies 22: 609-32. [CrossRef]

Bates, Laurie J., Carmelo Giaccotto, and Rexford E. Santerre. 2015. Is the Real Estate Sector More Responsive to Economy-Wide or Housing Market Conditions? An Exploratory Analysis. Journal of Real Estate Finance and Economics 51: 541-54. [CrossRef]

Bessembinder, Hendrik, Kalok Chan, and Paul J. Seguin. 1996. An empirical examination of information, differences of opinion, and trading activity. Journal of Financial Economics 40: 105-34. [CrossRef]

Bokhari, Sheharyar, and David Geltner. 2011. Loss Aversion and Anchoring in Commercial Real Estate Pricing: Empirical Evidence and Price Index Implications. Real Estate Economics 39: 635-70. [CrossRef]

Bris, Arturo, William N. Goetzmann, and Ning Zhu. 2007. Efficiency and the bear: Short sales and markets around the world. Journal of Finance 62: 1029-79. [CrossRef]

Cashman, George D., David M. Harrison, and Michael J. Seiler. 2014. Advisor Choice in Asia-Pacific Property Markets. Journal of Real Estate Finance and Economics 48: 271-98. [CrossRef]

Cashman, George D., David M. Harrison, and Michael J. Seiler. 2016. Capital Structure and Political Risk in Asia-Pacific Real Estate Markets. Journal of Real Estate Finance and Economics 53: 115-40. [CrossRef]

Chan, Sewin, Samuel Dastrup, and Ingrid Gould Ellen. 2016. Do Homeowners Mark to Market? A Comparison of Self-Reported and Estimated Market Home Values During the Housing Boom and Bust. Real Estate Economics 44: 627-57. [CrossRef]

Chen, Honghui, David H. Downs, and Gary A. Patterson. 2012. The Information Content of REIT Short Interest: Investment Focus and Heterogeneous Beliefs. Real Estate Economics 40: 249-83. [CrossRef]

Chuang, Wen-I., and Bong-Soo Lee. 2006. An empirical evaluation of the overconfidence hypothesis. Journal of Banking \& Finance 30: 2489-515.

Chuang, Wen-I., and Rauli Susmel. 2011. Who is the more overconfident trader? Individual vs. institutional investors. Journal of Banking \& Finance 35: 1626-44. [CrossRef]

Chuang, Wen-I., Bong-Soo Lee, and Kai-Li Wang. 2014. US and Domestic Market Gains and Asian Investors' Overconfident Trading Behavior. Financial Management 43: 113-48. [CrossRef]

Daniel, Kent, David Hirshleifer, and Avanidhar Subrahmanyam. 1998. Investor psychology and security market under- and overreactions. Journal of Finance 53: 1839-85. [CrossRef] 
De Bondt, Werner F. M., and Richard Thaler. 1985. Does the Stock-Market Overreact. Journal of Finance 40: $793-805$. [CrossRef]

Eichholtz, Piet, and Erkan Yönder. 2015. CEO Overconfidence, REIT Investment Activity and Performance. Real Estate Economics 43: 139-62. [CrossRef]

French, Kenneth R., G. William Schwert, and Robert F. Stambaugh. 1987. Expected Stock Returns and Volatility. Journal of Financial Economics 19: 3-29. [CrossRef]

Gervais, Simon, and Terrance Odean. 2001. Learning to be overconfident. Review of Financial Studies 14: 1-27. [CrossRef]

Glascock, John L., Chiuling Lu, and Raymond W. So. 2000. Further evidence on the integration of REIT, bond, and stock returns. Journal of Real Estate Finance and Economics 20: 177-94. [CrossRef]

Glaser, Markus, and Martin Weber. 2007. Overconfidence and trading volume. Geneva Risk and Insurance Review 32: 1-36. [CrossRef]

Glosten, Lawrence R., Ravi Jagannathan, and David E. Runkle. 1993. On the Relation between the Expected Value and the Volatility of the Nominal Excess Return on Stocks. Journal of Finance 48: 1779-801. [CrossRef]

Griffin, John M., Federico Nardari, and René M. Stulz. 2007. Do investors trade more when stocks have performed well? Evidence from 46 countries. Review of Financial Studies 20: 905-51. [CrossRef]

Grossman, Sanford J., and Joseph E. Stiglitz. 1980. On the Impossibility of Informationally Efficient Markets. American Economic Review 70: 393-408.

Hanauer, Matthias. 2014. Is Japan Different? Evidence on Momentum and Market Dynamics. International Review of Finance 14: 141-60. [CrossRef]

Hodrick, Robert J., and Edward C. Prescott. 1997. Postwar US business cycles: An empirical investigation. Journal of Money Credit and Banking 29: 1-16. [CrossRef]

Huang, MeiChi. 2013. The Role of People's Expectation in the Recent US Housing Boom and Bust. Journal of Real Estate Finance and Economics 46: 452-79. [CrossRef]

Ikromov, Nuriddin, and Abdullah Yavas. 2012. Asset Characteristics and Boom and Bust Periods: An Experimental Study. Real Estate Economics 40: 603-36. [CrossRef]

Janus, Thorsten, Yothin Jinjarak, and Manachaya Uruyos. 2013. Sovereign default risk, overconfident investors and diverse beliefs: Theory and evidence from a new dataset on outstanding credit default swaps. Journal of Financial Stability 9: 330-36. [CrossRef]

Karpoff, Jonathan M. 1987. The Relation between Price Changes and Trading Volume-A Survey. Journal of Financial and Quantitative Analysis 22: 109-26. [CrossRef]

Koop, Gary, M. Hashem Pesaran, and Simon M. Potter. 1996. Impulse response analysis in nonlinear multivariate models. Journal of Econometrics 74: 119-47. [CrossRef]

Kuo, Wei-Yu, and Tse-Chun Lin. 2013. Overconfident individual day traders: Evidence from the Taiwan futures market. Journal of Banking \& Finance 37: 3548-61.

Kyle, Albert S. 1985. Continuous Auctions and Insider Trading. Econometrica 53: 1315-35. [CrossRef]

Lin, Crystal Yan, Hamid Rahman, and Kenneth Yung. 2010. Investor Overconfidence in REIT Stock Trading. Journal of Real Estate Portfolio Management 16: 39-58. [CrossRef]

Liu, Yu, Paul Gallimore, and Jonathan A. Wiley. 2015. Nonlocal Office Investors: Anchored by their Markets and Impaired by their Distance. Journal of Real Estate Finance and Economics 50: 129-49. [CrossRef]

Lo, Andrew W., and Jiang Wang. 2000. Trading volume: Definitions, data analysis, and implications of portfolio theory. Review of Financial Studies 13: 257-300. [CrossRef]

Nneji, Ogonna, Chris Brooks, and Charles Ward. 2013. Commercial Real Estate and Equity Market Bubbles: Are They Contagious to REITs? Urban Studies 50: 2496-516. [CrossRef]

Odean, Terrance. 1998. Volume, volatility, price, and profit when all traders are above average. Journal of Finance 53: 1887-934. [CrossRef]

Odean, Terrance. 1999. Do investors trade too much? American Economic Review 89: 1279-98. [CrossRef]

Parker, Andrew M., Wändi Bruine De Bruin, Joanne Yoong, and Robert Willis. 2012. Inappropriate Confidence and Retirement Planning: Four Studies with a National Sample. Journal of Behavioral Decision Making 25: 382-89. [CrossRef] [PubMed]

Pesaran, H. Hashem, and Yongcheol Shin. 1998. Generalized impulse response analysis in linear multivariate models. Economics Letters 58: 17-29. [CrossRef] 
Ro, SeungHan, and Paul Gallimore. 2014. Real Estate Mutual Funds: Herding, Momentum Trading and Performance. Real Estate Economics 42: 190-222. [CrossRef]

Sakalaki, Maria, Clive Richardson, and Marina Bastounis. 2005. Association of economic internality with saving behavior and motives, financial confidence, and attitudes toward state intervention. Journal of Applied Social Psychology 35: 430-43. [CrossRef]

Shiller, Robert J. 1981. Do Stock-Prices Move Too Much to Be Justified by Subsequent Changes in Dividends. American Economic Review 71: 421-36.

Shiller, Robert J. 1983. Do Stock-Prices Move Too Much to Be Justified by Subsequent Changes in Dividends-Reply. American Economic Review 73: 236-37.

Statman, Meir, Steven Thorley, and Keith Vorkink. 2006. Investor overconfidence and trading volume. Review of Financial Studies 19: 1531-65. [CrossRef]

Tan, Kelvin Jui Keng. 2017. Why Do Overconfident REIT CEOs Issue More Debt? Mechanisms and Value Implications. Abacus-a Journal of Accounting Finance and Business Studies 53: 319-48. [CrossRef]

Xia, Tian, Zhengwei Wang, and Kunpeng Li. 2014. Financial Literacy Overconfidence and Stock Market Participation. Social Indicators Research 119: 1233-45. [CrossRef]

Yang, Jian, Yinggang Zhou, and Wai Kin Leung. 2012. Asymmetric Correlation and Volatility Dynamics among Stock, Bond, and Securitized Real Estate Markets. Journal of Real Estate Finance and Economics 45: 491-521. [CrossRef]

Yung, Kenneth, DeQing Diane Li, and Qian Susan Sun. 2015. CEO overconfidence and financial policies of real estate investment trusts (REITs). Journal of Property Research 32: 384-406. [CrossRef]

Zheng, Siqi, Weizeng Sun, and Matthew E. Kahn. 2016. Investor Confidence as a Determinant of China's Urban Housing Market Dynamics. Real Estate Economics 44: 814-45. [CrossRef]

(C) 2020 by the authors. Licensee MDPI, Basel, Switzerland. This article is an open access article distributed under the terms and conditions of the Creative Commons Attribution (CC BY) license (http://creativecommons.org/licenses/by/4.0/). 